\title{
CHARACTERIZATION AND FIELD PERFORMANCE OF 15 STRAWBERRY GERMPLASM UNDER BANGLADESH CONDITIONS
}

\author{
M. Moshiur Rahman ${ }^{1 *}$, M. Mizanur Rahman', M. Mofazzal Hossain ${ }^{2}$ \\ M. A. Khaleque $\mathrm{Mian}^{3}$ and Q. Abdul Khaliq ${ }^{4}$ \\ Pomology Division, Horticulture Research Centre, Bangladesh Agricultural Research Institute, \\ Joydebpur, Gazipur, Bangladesh
}

\begin{abstract}
Fifteen strawberry germplasm collected from local and exotic sources were evaluated for different qualitative and quantitative characters. The germplasm showed variation for majority of the studied traits. Plant height during peak harvest ranged from 14.67 to $25.00 \mathrm{~cm}$ and FA 007 exhibited the tallest plants. The maximum number of leaves plant ${ }^{-1}$ was produced by FA 006 (46.67). The maximum number of runners plant ${ }^{-1}$ was obtained in FA 003 (68.67) followed by FA 004 (63.00), while the highest number of crown plant $^{-1}$ was found in FA 007 (15.33) followed by FA 006 (14.67). Days to flowering varied from 48.33 to 102.30 among the germplasm and FA 008 required minimum (48.33) days for flowering. The germplasm FA 004 produced the highest number of flower trusses (35.50 plant $^{-1}$ ) while it was the lowest in FA $010\left(5.00\right.$ plant $\left.^{-1}\right)$. The number of flowers plant ${ }^{-1}$ was found maximum in FA 003 (168.00 plant $^{-1}$ ) and minimum in FA 010 (40.00 plant $\left.^{-1}\right)$. Among the germplasm pollen viability varied significantly and maximum viable pollen was recorded in FA 010 (84\%), while it was lowest in FA 004 $(12.00 \%)$. The highest per cent fruit set was recorded in BARI Strawberry-1 (86 \%) while, FA 013 (39\%) showed the lowest. Among the germplasm the highest yield plant ${ }^{-1}$ was recorded from FA 005 (737.70 g) followed by FA $006(702.30 \mathrm{~g})$ and was significantly higher than others while the lowest yield plant ${ }^{-1}$ was recorded from FA 013 (52.00 g), FA 014 (69.00 g), FA 009 (81.33 g) and FA $010(121.30 \mathrm{~g})$.
\end{abstract}

Keywords: Strawberry, qualitative growth characters, quantitative growth characters, reproductive characters

\footnotetext{
"Corresponding author email: moshiur.bari@yahoo.com

${ }^{1}$ Senior Scientific Officer, HRC, BARI, Gazipur, Bangladesh

${ }^{2}$ Professor, Department of Horticulture, BSMRAU, Salna, Gazipur, Bangladesh

${ }^{3}$ Professor, Department of Plant Breeding, BSMRAU, Salna, Gazipur, and

${ }^{4}$ Professor, Department of Agronomy, BSMRAU, Salna, Gazipur, Bangladesh
}

Received: 03.04.2013 


\section{INTRODUCTION}

Strawberries (Fragaria $\mathrm{x}$ ananassa Duch.) are widely grown fruit crop in the world, adapted in geographically diverse area (Biswas et al., 2009). Strawberry is now grown successfully in Bangladesh. There are more than 20 Fragaria species and numerous cultivars commercially cultivated in several countries (Gaafar and Saker, 2006). The cultivars vary remarkably in morphological characters (Biswas et al., 2009). The genotypic and phenotypic interaction of strawberry plant is highly cultivar dependent. Therefore, the choice of a cultivar is of paramount importance for successful strawberry cultivation (Asrey and Singh, 2004). On the other hand, as a new crop it is necessary to evaluate the morphological characters under Bangladesh condition. A germplasm collection with good variability for the desirable characters is the basic requirement of any crop improvement program (Singhania et al., 2006; AVRDC, 1990). In addition, crop improvement is primarily based on extensive evaluation of germplasm. Morphological characters of a plant is most important for nature as well as yield of a crop. Hence, studies about these important traits are necessary for successful cultivation of this crop in a new area like Bangladesh.

Bangladesh Agricultural Research Institute has released one variety of strawberry named BARI strawberry-1, which is not enough for increasing demand of strawberry cultivation. So, it is necessary to develop more variety of this promising crop. None of work based on field performance and morphological characterization of strawberry under Bangladesh condition was done. However, a good number of investigations were done in India, Pakistan and elsewhere in the world. Therefore, the present study was undertaken to characterize the collected strawberry germplasm for morphological characters and to select superior one on the basis of morphological characters.

\section{MATERIALS AND METHODS}

Experiment site: This study was conducted at the Fruit Research Farm of Horticulture Research Centre of Bangladesh Agricultural Research Institute, (Latitude $23^{0} 59^{\prime} \mathrm{N}$, Longitude $90^{\circ} 24^{\prime} \mathrm{E}$, Altitude $14.33 \mathrm{~m}$ ), Gazipur, Bangladesh during August 2008 to May 2010. This region falls in sub-tropical zone having hot summers (May-August) and mild winter (December-February). Cumulative rainfall of about $104-112 \mathrm{~mm}$ during cultivation period with average $79.4 \%$ relative humidity. The mean maximum and minimum temperature during cropping period were 25.89 and $17.05^{\circ} \mathrm{C}$, respectively. Soil of the experimental farm was clay loam, having $\mathrm{pH} 6.2$, which was low in organic carbon $(0.95 \%)$, very low in available phosphorus $(9 \mathrm{ppm})$ and low in potash $(0.17 \mathrm{meq} / 100 \mathrm{~g}$ soil $)$.

Treatments: Healthy and disease free daughter plants of 15 strawberry germplasm collected from local and exotic sources were considered as treatments and planted in the experimental field. The released strawberry variety in Bangladesh namely BARI Strawberry-1 was used as check (Appendix 1). 
Experimental design and layout: The experiment was laid out in a randomized complete block (RCB) design with three replications. The unit plot size was $100 \times 280 \mathrm{~cm}$ and the plants were spaced $50 \times 40 \mathrm{~cm}$ on open beds. Beds were raised $30 \mathrm{~cm}$ above main field with $50 \mathrm{~cm}$ drain in-between 2 beds. Each plot contained double row accommodating 14 plants. Daughter plants of strawberry germplasm were planted in September 15, 2008 and 2009. Data were collected from inner plants from each row to avoid border effect. In each unit plot ten inner plants were selected for recording data.

Intercultural operations: Runners were removed at every 3 to 4 days intervals in order to make the crown capable to initiate flowers. Straw mulch was applied around the plants as a normal practice in order to conserve soil moisture, decreasing weed and to avoid contact of the fruits with soil for reduction of rot caused by soil microbes. Weeds were removed whenever necessary to keep the crop weed free. Irrigation was given whenever necessary to keep soil moisture available in the field for better plant growth. All other necessary cultural practices and plant protection measures were followed uniformly for all the plots and treatments during the entire period of experimentation.

Observations recorded: Following vegetative characters viz. growth habit, plant vigor, foliage density, foliage color of strawberry plants and position of inflorescences were recorded by close observation according to the descriptor developed by IBPGR (1986). On the other hand, plant height $(\mathrm{cm})$, plant spread $(\mathrm{cm})$, leaves plant ${ }^{-1}$, runners plant ${ }^{-1}$, crowns plant ${ }^{-1}$, days to flowering, flower trusses plant ${ }^{-1}$, flowers plant ${ }^{-1}$, size of flower $(\mathrm{cm})$, disk size of flower (receptacle) $(\mathrm{cm})$, pollen viability (\%) and percent fruit set were recorded for quantitative growth characters of strawberry plants and yield plant ${ }^{-1}(\mathrm{~g})$.

Pollen viability (\%): Freshly opened flowers were collected to assess viability of the pollen grains. The pollen grains from the anther cone were dusted on a glass slide. Carmino Acetic Acid (CAA) solution (single drop) was used to stain the specimen and was covered with a cover slip. Pollen grains were viewed under a light microscope. The normal and properly stained pollen grains were considered as viable.

Data analysis: Two year's data of different quantitative parameters were pooled and analyzed, following RCB design using MSTAT-C (Nisen, 1983). The mean comparison was done following the Duncan's Multiple Range Test (DMRT).

\section{RESULTS AND DISCUSSION}

\section{Qualitative growth characters}

Growth habit: Regarding growth habit of plants, the germplasm were categorized into 3 types viz. erect, intermediate and prostrate (Table 1). Six germplasm (FA 001, BARI Strawberry-1, FA 005, FA 008, FA 013 and FA 014) 
exhibited intermediate type of growth habit, five germplasm (FA 004, FA 006, FA 007, FA 016 and FA 017) exhibited erect type of growth and rest of the germplasm exhibited prostrate type of growth habit. Meulenbroek et al. (2002) found that the plants of 'Pavana' variety exhibited open (prostrate) growth habit.

Plant vigor: Based on plant vigor, the germplasm were classified into 3 viz., weak, intermediate and strong (Table 1). Among 15 germplasm studied, strong vigorous plants were observed in 6 germplasm (FA 003, FA 004, FA 006, FA 007, FA 016 and FA 017); 5 germplasm (FA 001, BARI Strawberry-1, FA 005, FA 008 and FA 011) were intermediate and the rest 4 germplasm (FA 009, FA 010, FA 013 and FA 014) were weak in plant vigor. Ludvikova and Paprstein (2003) found that plants of 'Pegasus' and 'Honeoye' varieties were vigorous in nature. Their findings corroborated with the present observation.

Foliage density: Foliage densities of strawberry plants were classified into sparse, intermediate and dense (Table 1). Among the germplasm plants of 7 germplasm (FA 001, BARI Strawberry-1, FA 005, FA 010, FA 011, FA 013 and FA 014) showed intermediate, 5 germplasm (FA 004, FA 006, FA 007. FA 016 and FA 017) showed dense and remaining 3 (FA 003, FA 008 and FA 009) sparse type of foliage. Ludvikova and Paprstein (2003) found that the variety 'Pegasus' was dense and 'Honeoye' was intermediate in nature. Results of their findings are similar to the present observation.

Foliage color: Foliage coloration of plants was groped into light, intermediate and dark (Table 1). Among the germplasm, 8 (FA 001, BARI Strawberry-1, FA 003, FA 008, FA 009, FA 011, FA 013 and FA 014) were dark in foliage color; 2 (FA 004 and FA 010) germplasm were intermediate and plants of rest germplasm (FA 005, FA 006, FA 007. FA 016 and FA 017) were light in color.

Position of inflorescences: Positions of inflorescences in different germplasm were categories into beneath, level with and above the foliage (Table 1). Among the studied germplasm, it was found that the plants of 9 germplasm (FA 003, FA 004, FA 005, FA 006, FA 007, FA 010, FA 011, FA 016 and FA 017) produced inflorescences, which were beneath the foliage. Inflorescences of 4 germplasm (FA 001, BARI Strawberry-1, FA 008 and FA 013) were above the foliage and rest two germplasm (FA 009 and FA 014) produced inflorescences level with the foliage (Table 1). The germplasm having inflorescences above the foliage was suitable for harvesting. Meulenbrock et al. (2002) found that cultivar 'Pavana' had long flower clusters that make the fruit easy to pick.

\section{Quantitative growth characters}

Plant height: Significant variation among the germplasm was observed for plant height. The tallest plant $(25.00 \mathrm{~cm})$ was recorded in the genotype FA 007 and the shortest $(14.67 \mathrm{~cm}$ ) in the genotype FA 013 (Table 2). The variation in plant height might be due to the genetic makeup. Results of present investigation regarding plant height were partial 
agreement with the findings of Rahman (2011), and Asrey and Singh (2004). Riyaphan et al. (2005) obtained significant variation in plant height of strawberry plants in Thailand, which ranged from 10 to $20 \mathrm{~cm}$ at mid-harvesting time.

Plant spread: Significant variation among the germplasm was observed for plant spread. The highest plant spread $(24.67 \mathrm{~cm})$ was recorded in the genotype FA 005 and FA 006, and the lowest $(15.00 \mathrm{~cm})$ in the genotype FA 013 (Table 2). The variation in plant size might be due to the genetic makeup of strawberry plants. Asrey and Singh (2004) and Rahman (2011) found a significant variation in plant spread. Results of present investigation regarding plant size was in agreement with the findings of Asrey and Singh (2004) and Rahman (2011).

Leaves plant $^{-1}$ : Leaf number is important for photosynthesis and it differed significantly ranging from 46.67 (FA 006) to 20.33 (FA 014). Among the germplasm, FA 006 produced the maximum number of leaves and FA 014 produced the minimum (Table 2.). The number of leaf plant $^{-1}$ in different germplasm varied mainly due to inherent characters of the germplasm. Rahman (2011) obtained the number of leaves plant ${ }^{-1}$ varying from 60.52 to 49.00 in different germplasm which was more or less closer to the findings of the present study. But the finding about leaves plant ${ }^{-1}$ reported by Asrey and Singh (2004) was lower than the present study. They found that number of leaves ranged from 3.33 to 6.33 plant $^{-1}$ under irrigation in semi-arid region of Punjab, which might be due to the genetic as well as the environmental effect. Perez-de-Camacaro et al. (2002) obtained a variation in leaf number among cultivars during the later part of the season and found that cv. 'Bolero' and 'Everest' produced the highest and 'Elsanta' the least number of leaves plant ${ }^{-1}$. In another study revealed a significant variation in leaves plant ${ }^{-1}$ among strawberry germplasm and recorded 4.6 to 9.8 leaves plant ${ }^{-1}$ at 86 days after planting in Cambridge.

Number of runner and crown plant $^{-1}$ : Significant variation among the germplasm was observed in respect of numbers of runner and crown plant ${ }^{-1}$. Among the germplasm, FA 003 produced the highest number of runner (68.67) followed by FA 004 (63.00) while FA 007 produced the lowest (6.33). FA 007 produced the maximum number of crown (15.33) followed by FA 006 (14.67) and FA 005 (11.33), while FA 009 and FA 011 produced the lowest (6.67) (Table 2.). The variation in different germplasm as recorded might be due to genetic makeup. This result is in confirmatory with the findings of Pérez-de-Camacaro et al. (2002). They found a significant difference in number of runner and crown plant ${ }^{-1}$ among the strawberry cultivars in UK. 'Elsanta' produced more runners than 'Bolero' and 'Everest'. While cv. 'Bolero' produced more crowns than 'Everest' and 'Elsanta'. In the present study, FA 005, FA 006 and FA 007 produced the minimum number of runners but the maximum number of crowns. This result is at par with that of Riyaphan et al. (2005). They found significant variation in numbers of runners and crowns plant ${ }^{-1}$ and reported that $\mathrm{cv}$. 'Tioga' produced the maximum number of crowns and the minimum number of runners in Thailand. 
Relationship between runner and crown per plant: A negative linear relationship was observed between number of crown per plant and number of runner per plant (Figure 1). The equation was $y=-0.0952 x+12.612$ and the value of the coefficient of determination $\left(\mathrm{R}^{2}=0.4801\right)$ gave a good fit and the fitted regression line had a significant regression coefficient, indicating number of crown plant $^{-1}$ will be increased with a significant manner with the decrease of number of runner plant ${ }^{-1}$. So, there is a clear indication that higher number of runners inhibited the crown producing ability of strawberry plants. This result is in strong agreement with that of Riyaphan et al. (2005).

\section{Reproductive characters}

Days to flowering: Significant variation among the germplasm in relation to days to flowering was observed. The maximum number of days (102.3) was required for flowering in FA 004 and the minimum (48.33 days) in FA 008 (Table 3). This is because FA 008 might be early genotype. It is in agreement with the findings of Riyaphan et al. (2005) who recorded that number of days from transplanting to first blooming ranged from 67.50 to $78.90 \mathrm{in} \mathrm{cv}$. 'Tioga' and from 40.80 to $47.23 \mathrm{in} \mathrm{cv}$. 'Tochiotome'. Asrey and Singh (2004) found a significant variation in days to flowering, which is also in consonant with the present findings. They found that strawberry cultivar 'Seascape' required maximum number of days for flowering followed by 'Chandler', while minimum in Fern. Rahman (2011) found that days to flowering varied significantly among the strawberry germplasm and it ranged from 72.42 to 81.87 days. Macit et al. (2007) reported that 'Sweet Charlie' and 'Camarosa' were earlier in first flowering than other varieties, while Kabarla was late under conventional system in Samsun, Turkey.

Flower trusses and flowers plant ${ }^{-1}$ : Marked variation was observed among the germplasm for number of flower trusses (inflorescences) and flowers plant ${ }^{-1}$. Among the germplasm, FA 004 produced maximum number of flower trusses plant ${ }^{-1}$ (35.5), while FA 010 produced only 5 flower trusses plant ${ }^{-1}$. During the study period, the highest number of flowers plant ${ }^{-1}$ (168) was observed in FA 003 followed by FA 016 (145), FA 017 (144) and FA 004 (142), which were statistically similar; while the lowest was in FA 010 (40) shown in table 1.3.3. The number of flower trusses and flowers plant ${ }^{-1}$ in different germplasm varied mainly due to inherent mechanism of the germplasm. This result was partially similar with that of Rahman et al. (2011), who found that number of flower trusses and number of flowers plant ${ }^{-1}$ differed significantly among the germplasm, ranged from 6.58 to 8.10 and from 37.11 to 53.42, respectively. Michel et al. (2006) found that the total number of flowers plant ${ }^{-1}$ was linearly related to its number of inflorescences (trusses). They found on an average 25.90 flowers inflorescence ${ }^{-1}$. But Sønsteby and Heide, (2008) recorded less number of inflorescences with a more number of flowers plant ${ }^{-1}$ in cv. 'Korona'. Riyaphan et al. (2005) and Pérez-de-Camacaro et al. (2002) found that the number of inflorescences plant ${ }^{-1}$ significantly varied in strawberry cultivars, which are in close conformity with the present findings. They also observed that the early flowering germplasm produced less number of trusses as well as flowers 
plant ${ }^{-1}$ compared to late flowering germplasm. This the fact might be due to that the early flowering germplasm produced inflorescences before optimum vegetative growth, which might have suppressed inflorescences and flowers number plant ${ }^{-1}$. On the other hand, late flowering germplasm reach reproductive phase after attaining optimum vegetative growth, which might enhance flowering potentiality. In addition, the early flowering germplasm produced flower under higher temperature which have negative impact on inflorescences and flower production. These observations are supported by the findings of Patterson (1995) and Chercuitte et al. (1991), while Maurer and Umeda (1999) found that irrespective of flowering time, flowers number plant $^{-1}$ varied significantly among the germplasm.

Relationship between days to flowering and flower trusses plant ${ }^{-1}$ : A positive quadratic relationship was observed between days to flowering and flower trusses plant ${ }^{-1}$ (Figure 2). The equation was $\mathrm{y}=-138.92+4.1467 \mathrm{x}-0.0241 \mathrm{x}^{2}$ and the value of the coefficient of determination $\left(\mathrm{R}^{2}=0.7786\right)$ was significant at $5 \%$ level of probability, indicating flower trusses plant ${ }^{-1}$ increased with a significant manner with the increase of days to flowering up to 85 days. So, there is a clear indication that early flowering germplasm produced less number of flower trusses plant ${ }^{-1}$ compared to late flowering germplasm. This result is in line with the findings of Patterson (1995) and Chercuitte et al. (1991). But flower trusses decreased in those plants that required more than 85 days for earlier flowering. This might be due to extreme delayed plants flowered at higher temperature which inhibited flowering in strawberry. Ledesma et al. (2008) found comparatively high temperature significantly reduced the number of inflorescences in strawberry.

Size of flower: Size of flower in respect of diameter and thickness varied significantly. This might be due to genetic variation among the germplasm. Among the germplasm FA 007 produced the largest flower in respect of diameter and thickness (3. $43 \mathrm{~cm}$ and $2.07 \mathrm{~cm}$, respectively) followed by FA $006(3.30 \mathrm{~cm}$ and $2.03 \mathrm{~cm}$, respectively), while FA 004 produced the smallest flower having the lowest diameter $(2.07 \mathrm{~cm})$ and thickness $(0.87 \mathrm{~cm})$ and shown in table 4 . This result is in agreement with the findings of Rahman (2011) and Verma et al. (2002), who found that diameter and thickness of flower ranged from 1.74 to $2.44 \mathrm{~cm}$ and 1.40 to $2.36 \mathrm{~cm}$, respectively.

Disk size of flower (receptacle): Size of receptacle (disk) of flower in respect of diameter and thickness varied significantly. Among the genotype FA 006 produced flowers having the biggest receptacle in respect of diameter $(2.60 \mathrm{~cm})$ while, FA 004 produced flowers with the smallest receptacle diameter $(1.33 \mathrm{~cm})$. The thickest receptacle was found in the flowers of FA $007(1.60 \mathrm{~cm})$ and the thinnest receptacle was found in the flowers of FA 004 and FA 003 (Table 4). Rahman (2011) and Verma et al. (2002) found that flower disk diameter and thickness differed significantly among the germplasm ranging from 0.66 to $0.90 \mathrm{~cm}$. and $0.31 \mathrm{~cm}$ to $0.65 \mathrm{~cm}$, respectively which were lower compared to present observation. This might be due to difference of cultivation or the growing environment. 
Pollen viability: Pollen viability is one of the most important attributes for proper fruit setting. The germplasm varied significantly in respect of pollen viability. The maximum viable pollens were found in FA $010(84.00 \%)$ followed by FA $008(81.67$ $\%)$, FA $001(81.33 \%)$ and BARI Strawberry-1 (76.00\%) and those were statistically similar, but the lowest viable pollen grains were found in FA $004(12.00 \%)$ and FA 003 $(12.33 \%)$ (Table 4). Such variation in pollen variability might be due to the influence of ploidy level and effect of high temperature which prevailed during the time of flowering in these two germplasm. Ledesma and Sugiyama (2005) stated that pollen viability of strawberry varied significantly among the germplasm, which was supported by the present observation. Such variation might be due to the effect of germplasm, temperature and their interaction. In addition, pollen quality was also influenced by high temperature, but the effect of higher temperature on pollen viability is cultivar specific. According to Kronenberg (1959), pollen viability differs among strawberry cultivars which affect the fruit set and yield of strawberry.

Per cent fruit set: The number of fruit set is directly dependent on the abundance of flowers and their existence in the plant which was controlled by environment and genetic makeup of the germplasm. The highest per cent fruit set was recorded in BARI Strawberry-1 (86 \%) followed by FA $008(81 \%)$ and FA 010 (73 $\%)$ and they were statistically similar, and significantly higher than rest of the germplasm while FA 013 (39 \%) showed the lowest (Figure 3). Among the germplasm FA 003 and FA 004 failed to produce any fruit due to very poor pollen viability (Table 4). The variation in different germplasm is due to variation of genetic makeup and differential response of the germplsam to climatic conditions of the locality. Ledesma et al. (2008) found that per cent fruit set of strawberry varied significantly among the cultivars ranging from 60.20 to 92.40 they also observed a significant interaction between temperature and cultivars regarding fruit set (\%) which was similar to the results of the present experiment.

Relationship between pollen viability and percent fruit set: A positive linear relationship was observed between pollen viability (\%) and per cent fruit set (Figure 4). The equation was $y=1.1062 x-17.108$ and the value of the coefficient of determination $\left(\mathrm{R}^{2}=0.8139\right)$ gave a fitted regression line and indicating a significant regression coefficient, representing fruit set will be increased with a significant manner with the increase of pollen viability (\%). So, there is a clear indication that increase in percent pollen viability has significant positive effect on percent fruit set. Abdul-baki and Stommel, (1995) and Cross et al. (2003) stated that fruit set was directly hampered by poor pollen performance. Their results are strongly supported by the present findings.

Yield plant ${ }^{-1}$ : Among the germplasm the highest yield plant $^{-1}$ was recorded from FA $005(737.70 \mathrm{~g})$ followed by FA $006(702.30 \mathrm{~g})$ and was significantly higher than others (Figure 5). The lowest yield plant $^{-1}$ was recorded from FA 013, FA 014, FA 009 and FA 010 which produced only $52.00 \mathrm{~g}, 69.00 \mathrm{~g}, 81.33 \mathrm{~g}$ and $121.30 \mathrm{~g}$ fruits plant ${ }^{-1}$, 
respectively. The variation in yield plant $^{-1}$ was due to the inherent character of the germplasm. Rahman (2011) found that yield of strawberry varied significantly and ranged from 442.50 to $129.85 \mathrm{~g}$. Present findings was consonant with the results of Rahman (2011). From different experiments Pires et al. (2006) and Crespo (2010) stated that fruit yield plant ${ }^{-1}$ in strawberry varied significantly among the cultivars studied which were strongly supported by the present result.

\section{CONCLUSION}

The germplasm of strawberries showed variation in morphological as well as quantitative traits and also in yield plant $^{-1}$. On the basis of physico-morphological characters, it was concluded that genotype FA 006 and FA 007 were identical with FA 016 and FA 017, respectively. On the basis of different physico-morphological characters along with the higher yield plant ${ }^{-1}$ the germplasm FA 005, FA 006 and FA 007 were selected for further investigation On the other hand, based on poor pollen viability, poor fruit set as well as low yield plant ${ }^{-1}$ the germplasm FA 003 and FA 004 were discarded.

\section{REFERENCES}

Abdul-baki, A. A. and J. R. Stommel. 1995. Pollen viability and fruit-set of tomato genotypes under optimum- temperature and high-temperature regimes. Horticultural Science, 30:115-117

Asrey, R., R. K. Jain and R. Singh. 2004. Effect of pre-harvest chemical treatments on shelf life of Chandler strawberry. Indian Journal of Agricultural Sciences, 74: 485-487

AVRDC. 1990. Training Manual on Vegetable Production. Shanhua, Tainan, Taiwan. Asian Vegetable Research and Development Centre (AVRDC). Pp, 87-184

Biswas, M. K., M. Dutt, U. K. Roy, R. Islam and M. Hossain. 2009. Development and evaluation of in vitro somaclonal variation in strawberry for improved horticultural traits. Scientia Horticulturae, 122: 409-416

Crespo, P. 2010. Variability of Health and Taste Promoting Compounds in Strawberry (Fragaria $x$ ananassa) Fruits. Ph. D. Thesis. Swiss Federal Institute of Technology, E T H, Zurich, Switzerland. pp. 10-86.Chercuitte, L., J. A. Sullivan, Y. D. Desjardins and R. Bedard. 1991. Yield potential and vegetative growth of summer-planted strawberry. Journal of American Society for Horticultural Science, 116(6): 930-936

Cross, R. H., S. A. B. Makay, A. G. Mchughen and P. C. Bonham-Smith. 2003. Heat-stress effect on reproduction and seed set in Linum usitatissimum L. (Flax). Plant Cell and Environment, 26: 1013-1020

Gaafar, R. M. and M. M. Saker. 2006. Monitoring of cultivars identity and genetic stability in strawberry varieties grown in Egypt. World Journal of Agricultural Science, 2 (1): 29-36

IBPGR. 1986. Strawberry Descriptor (Fragaria L.). International Board for Plant Genetic Resources. CEC Secretariat, Rome

Kronenberg, H. G. 1959. Poor fruit setting in strawberries. I. Causes of poor fruit setting in strawberries in general. Euphytica, 8: 47-57 
Ledesma, N. A. and N. Sugiyama. 2005. Pollen quality and performance in strawberry plants exposed to high-temperature stress. Journal of American Society for Horticultural Science, 130(3): 341-347

Ledesma, N. A., M. Nakata and N. Sugiyama. 2008. Effect of high temperature stress on the reproductive growth of strawberry cvs. 'Nyoho' and 'Toyonoka'. Scientia Horticulturae, 116: $186-193$

Ludvikova, J and F. Paprstein. 2003. Strawberry cultivar 'Pegasus' and 'Honeoye'. Vedecke-PraceOvocnarske, 18: 169-174

Macit, I., A. Koc, S. Guler and I. Deligoz. 2007. Yield, quality and nutritional status of organically and conventionally grown strawberry cultivar. Asian Journal of Plant Science, 6(7): 11311136

Maurer, M. A. and K. Umeda. 1999. Influence of cultivar and planting time on strawberry growth and development in the low desert. Vegetable Report. Arizona College of Agriculture. In: http://ag.arizona.edu/pubs/crops/az1143/

Meulenbroek, E. J., C. P. J. van-de Lindeloof and H. J. Kanne. 2002. "Pavana" a new strawberry cultivar from Plant Research International. Acta Horticulturae, 567(1): 183-185

Nisen, O.1983. MSTAT-C: A microcomputer program for the design, management and analysis of agronomic research experiments. Michigan State University

Patterson, W. K. 1995. Influence of planting time on 'Chandler' strawberry fields. Hort Science, 30(3): 436

Pérez de Camacaro, M. E., G. J. Camacaro, P. Hadley, N. H. Battey and J. G. Carew. 2002. Pattern of growth and development of the strawberry cultivars Elsanta, Bolero and Everest. Journal of American Society for Horticultural Science, 127(6): 901-907

Pires. R. C. M., M. V. Folegatti, F. A. Passos3; F. B. Arruda and E. Sakai. 2006. Vegetative growth and yield of strawberry under irrigation and soil mulches for different cultivation environments. Journal of Agricultural Science, 63 (5): 417-425.Rahman S. M. L. 2011. Production Technology of strawberry in Bangladesh. Ph. D. Thesis. Department of Horticulture, BSMRAU, Salna, Gazipur. pp. 49-105

Riyaphan, P., N. Pipattanawong and S. Subhadrabandu. 2005. Influence of different climatic conditions on growth and yield of strawberry plants in Thailand. In: Production technology for low-chill temperate fruits. A. P. George and U. Boonprakob (ed.), ACIAR Technical Report. 61:65-72

Rahman, S.M.L. 2011. Production Technology of Strawberry in Bangladesh. Ph.D thesis Department of Horticulture. BSMRAU, Salna, Gazipur, pp. 49-105

Singhania, D. L., D. Singh and R. S. Raje. 2006. Coriander. In: Ravindran, P. R. K. N. Babu, K. N. Shiva and J. A. Kallupurackal (eds.). Advances in Spices and Achievements of Spices Research in India. Agrobios, Agro House,Chopasani Road, Jodhpur, 342002. pp. 678-695.

Sønsteby, A. and O. M. Heide. 2008. Temperature responses, flowering and fruit yield of the Junebearing strawberry cultivars Florence, Frida and Korona. Scientia Horticulturae, 119: 49-54

Verma, S. K., R. K. Singh and R. R. Arya. 2002. Variability and correlation studies in strawberry genotypes for quantitative traits. Indian Journal of Horticulture, 59(1): 39-43 
Table 1: Qualitative growth characters of strawberry germplasm

\begin{tabular}{ll|l|l|l|l}
\hline \multicolumn{1}{c}{ Germplasm } & Growth habit & plant vigor & $\begin{array}{r}\text { Foliage } \\
\text { density }\end{array}$ & Foliage color & Position of inflorescences \\
\hline FA 001 & Intermediate & Intermediate & Intermediate & Dark & Above the foliage \\
FA 003 & Prostrate & Strong & Sparse & Dark & Beneath the foliage \\
FA 004 & Erect & Strong & Dense & Intermediate & Beneath the foliage \\
FA 005 & Intermediate & Intermediate & Intermediate & Light & Beneath the foliage \\
FA 006 & Erect & Strong & Dense & Light & Beneath the foliage \\
FA 007 & Erect & Strong & Dense & Light & Beneath the foliage \\
FA 008 & Intermediate & Intermediate & Sparse & Dark & Above the foliage \\
FA 009 & Prostrate & Weak & Sparse & Dark & Level with the foliage \\
FA 010 & Prostrate & Weak & Intermediate & Intermediate & Beneath the foliage \\
FA 011 & Prostrate & Intermediate & Intermediate & Dark & Beneath the foliage \\
FA 013 & Intermediate & Weak & Intermediate & Dark & Above the foliage \\
FA 014 & Intermediate & Weak & Intermediate & Dark & Level with the foliage \\
FA 016 & Erect & Strong & Dense & Light & Beneath the foliage \\
FA 017 & Erect & Strong & Dense & Light & Beneath the foliage \\
BARI Sb.-1 & Intermediate & Intermediate & Intermediate & Dark & Above the foliage \\
\hline
\end{tabular}

Table 2: Quantitative growth characters of strawberry germplasm

\begin{tabular}{|c|c|c|c|c|c|}
\hline Germplasm & $\begin{array}{c}\text { Plant height } \\
\text { (cm) }\end{array}$ & $\begin{array}{l}\text { Plant } \\
\text { spreading } \\
\text { (cm) }\end{array}$ & Leaves plant ${ }^{-1}$ & $\begin{array}{l}\text { Runners } \\
\text { plant }^{-1}\end{array}$ & Crowns plant ${ }^{-1}$ \\
\hline FA 001 & $15.33 \mathrm{de}$ & $22.00 \mathrm{ab}$ & $31.00 \mathrm{e}$ & $44.67 \mathrm{c}$ & $7.33 \mathrm{~cd}$ \\
\hline FA 003 & $16.33 \mathrm{de}$ & $23.33 \mathrm{a}$ & $34.00 \mathrm{de}$ & $68.67 \mathrm{a}$ & $9.00 \mathrm{~b}-\mathrm{d}$ \\
\hline FA 004 & $17.00 \mathrm{~d}$ & $21.67 \mathrm{ab}$ & $36.67 \mathrm{~cd}$ & $63.00 \mathrm{a}$ & $9.67 \mathrm{bc}$ \\
\hline FA 005 & $21.67 \mathrm{bc}$ & $24.67 \mathrm{a}$ & $42.67 \mathrm{~b}$ & $11.67 \mathrm{f}$ & $11.33 \mathrm{~b}$ \\
\hline FA 006 & $22.67 \mathrm{~b}$ & $24.67 \mathrm{a}$ & $46.67 \mathrm{a}$ & $8.33 \mathrm{f}$ & $14.67 \mathrm{a}$ \\
\hline FA 007 & $25.00 \mathrm{a}$ & $24.33 \mathrm{a}$ & $40.00 \mathrm{bc}$ & $6.33 \mathrm{f}$ & $15.33 \mathrm{a}$ \\
\hline FA 008 & $16.67 \mathrm{de}$ & $23.00 \mathrm{a}$ & $20.67 \mathrm{f}$ & $31.33 \mathrm{~d}$ & $8.67 \mathrm{~b}-\mathrm{d}$ \\
\hline FA 009 & $15.67 \mathrm{de}$ & $20.00 \mathrm{a}-\mathrm{c}$ & $21.33 \mathrm{f}$ & $44.33 \mathrm{c}$ & $6.67 \mathrm{~d}$ \\
\hline FA 010 & $15.00 \mathrm{de}$ & $18.00 \mathrm{~b}-\mathrm{d}$ & $21.00 \mathrm{f}$ & $43.00 \mathrm{c}$ & $7.00 \mathrm{~cd}$ \\
\hline FA 011 & $15.00 \mathrm{de}$ & $18.00 \mathrm{~b}-\mathrm{d}$ & $23.67 \mathrm{f}$ & $53.00 \mathrm{~b}$ & $6.67 \mathrm{~d}$ \\
\hline FA 013 & $14.67 \mathrm{e}$ & $15.00 \mathrm{~d}$ & $21.33 \mathrm{f}$ & $53.67 \mathrm{~b}$ & $7.00 \mathrm{~cd}$ \\
\hline FA 014 & $17.00 \mathrm{~d}$ & $16.00 \mathrm{~cd}$ & $20.33 \mathrm{f}$ & $43.00 \mathrm{c}$ & $7.33 \mathrm{~cd}$ \\
\hline FA 016 & $20.00 \mathrm{c}$ & $21.67 \mathrm{ab}$ & $40.00 \mathrm{bc}$ & $19.33 \mathrm{e}$ & $9.00 \mathrm{~b}-\mathrm{d}$ \\
\hline FA 017 & $21.33 \mathrm{bc}$ & $23.33 \mathrm{a}$ & $40.67 \mathrm{bc}$ & $20.67 \mathrm{e}$ & $9.00 \mathrm{~b}-\mathrm{d}$ \\
\hline $\begin{array}{l}\text { BARI Strawberry- } \\
1\end{array}$ & $17.00 \mathrm{~d}$ & $23.00 \mathrm{a}$ & $31.33 \mathrm{e}$ & $33.33 \mathrm{~d}$ & $8.67 \mathrm{~b}-\mathrm{d}$ \\
\hline $\begin{array}{l}\text { Level of } \\
\text { significance }\end{array}$ & $* *$ & $* *$ & $* *$ & $* *$ & $* *$ \\
\hline CV (\%) & 4.82 & 8.69 & 5.55 & 7.49 & 12.24 \\
\hline
\end{tabular}

Figures having the same letter(s) in a column do not differ significantly by DMRT.

Level of significance $* *$ means significant at $1 \%$ level 
Table 3: Days to flowering, flower trusses per plant and flowers per plant 16 in strawberry germplasm

\begin{tabular}{|c|c|c|c|}
\hline Germplasm & Days to flowering & Flower trusses plant $^{-1}$ & Flowers plant $^{-1}$ \\
\hline FA 001 & $55.67 \mathrm{e}-\mathrm{g}$ & $5.70 \mathrm{gh}$ & $74.10 \mathrm{c}-\mathrm{e}$ \\
\hline FA 003 & $95.67 \mathrm{~b}$ & $33.60 \mathrm{a}-\mathrm{c}$ & $168.00 \mathrm{a}$ \\
\hline FA 004 & $102.3 \mathrm{a}$ & $35.50 \mathrm{a}$ & $142.00 \mathrm{ab}$ \\
\hline FA 005 & $61.33 \mathrm{de}$ & $34.00 \mathrm{ab}$ & $136.00 \mathrm{~b}$ \\
\hline FA 006 & $66.33 \mathrm{~cd}$ & $31.50 \mathrm{~b}-\mathrm{d}$ & $135.40 \mathrm{~b}$ \\
\hline FA 007 & $69.33 \mathrm{c}$ & $31.00 \mathrm{~cd}$ & $124.00 \mathrm{~b}$ \\
\hline FA 008 & $48.33 \mathrm{~h}$ & $6.70 \mathrm{gh}$ & $80.40 \mathrm{~cd}$ \\
\hline FA 009 & $56.67 \mathrm{ef}$ & $6.00 \mathrm{gh}$ & $42.00 \mathrm{f}$ \\
\hline FA 010 & $50.33 \mathrm{f}-\mathrm{h}$ & $5.00 \mathrm{~h}$ & $40.00 \mathrm{f}$ \\
\hline FA 011 & $52.00 \mathrm{f}-\mathrm{h}$ & $14.50 \mathrm{e}$ & $65.25 \mathrm{c}-\mathrm{f}$ \\
\hline FA 013 & $49.67 \mathrm{gh}$ & $11.50 \mathrm{f}$ & $46.00 \mathrm{ef}$ \\
\hline FA 014 & $50.00 \mathrm{gh}$ & $11.60 \mathrm{f}$ & $52.20 \mathrm{~d}-\mathrm{f}$ \\
\hline FA 016 & $61.67 \mathrm{de}$ & $29.00 \mathrm{~d}$ & $145.00 \mathrm{ab}$ \\
\hline FA 017 & $64.00 \mathrm{~cd}$ & $32.00 \mathrm{bc}$ & $144.00 \mathrm{ab}$ \\
\hline BARI Strawberry-1 & $49.67 \mathrm{gh}$ & $8.40 \mathrm{~g}$ & $84.00 \mathrm{c}$ \\
\hline Level of sig. & $* *$ & $* *$ & $* *$ \\
\hline CV (\%) & 4.29 & 6.08 & 12.58 \\
\hline
\end{tabular}

Figures having the same letter(s) in a column do not differ significantly by DMRT.

Level of significance ** means significant at $1 \%$ level.

Table 4: Size of flower, size of flower disk and per cent pollen viability in strawberry

\begin{tabular}{c|c|c|c|c|c}
\hline \multirow{2}{*}{ Germplasm } & \multicolumn{2}{|c|}{ Size of flower (cm) } & \multicolumn{2}{c|}{ Size of flower disk (cm) } & \multirow{2}{*}{ Pollen viability (\%) } \\
\cline { 2 - 4 } & Diameter & Thickness & Diameter & Thickness & \\
\hline FA 001 & $2.97 \mathrm{~d}$ & $1.37 \mathrm{a}-\mathrm{d}$ & $2.13 \mathrm{~cd}$ & $1.10 \mathrm{~cd}$ & $81.33 \mathrm{ab}$ \\
FA 003 & $2.13 \mathrm{fg}$ & $0.87 \mathrm{~d}$ & $1.43 \mathrm{gh}$ & $0.60 \mathrm{e}$ & $12.33 \mathrm{~g}$ \\
FA 004 & $2.07 \mathrm{~g}$ & $0.87 \mathrm{~d}$ & $1.33 \mathrm{~h}$ & $0.60 \mathrm{e}$ & $12.00 \mathrm{~g}$ \\
FA 005 & $3.20 \mathrm{bc}$ & $1.90 \mathrm{a}-\mathrm{c}$ & $2.50 \mathrm{ab}$ & $1.47 \mathrm{ab}$ & $74.67 \mathrm{~b}-\mathrm{d}$ \\
FA 006 & $3.30 \mathrm{ab}$ & $2.03 \mathrm{ab}$ & $2.60 \mathrm{a}$ & $1.47 \mathrm{ab}$ & $66.33 \mathrm{~d}-\mathrm{f}$ \\
FA 007 & $3.43 \mathrm{a}$ & $2.07 \mathrm{a}$ & $2.30 \mathrm{bc}$ & $1.60 \mathrm{a}$ & $69.67 \mathrm{c}-\mathrm{e}$ \\
FA 008 & $2.97 \mathrm{~d}$ & $1.43 \mathrm{a}-\mathrm{d}$ & $1.97 \mathrm{de}$ & $1.10 \mathrm{~cd}$ & $81.67 \mathrm{ab}$ \\
FA 009 & $2.37 \mathrm{e}$ & $1.27 \mathrm{~cd}$ & $1.80 \mathrm{ef}$ & $0.83 \mathrm{de}$ & $64.33 \mathrm{ef}$ \\
FA 010 & $2.33 \mathrm{ef}$ & $1.17 \mathrm{~cd}$ & $1.67 \mathrm{fg}$ & $0.83 \mathrm{de}$ & $84.00 \mathrm{a}$ \\
FA 011 & $2.30 \mathrm{ef}$ & $1.27 \mathrm{~cd}$ & $1.63 \mathrm{fg}$ & $0.83 \mathrm{de}$ & $74.33 \mathrm{~b}-\mathrm{d}$ \\
FA 013 & $2.23 \mathrm{e}-\mathrm{g}$ & $1.30 \mathrm{~b}-\mathrm{d}$ & $1.60 \mathrm{f}-\mathrm{h}$ & $0.87 \mathrm{de}$ & $69.33 \mathrm{c}-\mathrm{e}$ \\
FA 014 & $2.33 \mathrm{ef}$ & $1.27 \mathrm{~cd}$ & $1.80 \mathrm{ef}$ & $0.87 \mathrm{de}$ & $60.00 \mathrm{f}$ \\
FA 016 & $3.03 \mathrm{~cd}$ & $1.60 \mathrm{a}-\mathrm{d}$ & $2.23 \mathrm{~b}-\mathrm{d}$ & $1.37 \mathrm{a}-\mathrm{c}$ & $72.33 \mathrm{c}-\mathrm{e}$ \\
FA 017 & $3.17 \mathrm{~b}-\mathrm{d}$ & $1.67 \mathrm{a}-\mathrm{c}$ & $2.13 \mathrm{~cd}$ & $1.43 \mathrm{ab}$ & $73.33 \mathrm{~b}-\mathrm{d}$ \\
BARI Strawberry-1 & $3.03 \mathrm{~cd}$ & $1.53 \mathrm{a}-\mathrm{d}$ & $2.23 \mathrm{~b}-\mathrm{d}$ & $1.23 \mathrm{bc}$ & $76.00 \mathrm{a}-\mathrm{c}$ \\
\hline Level of significance & $* *$ & $* *$ & $* *$ & $* *$ & $*$ \\
\hline CV (\%) & $\mathbf{3 . 1 4}$ & $\mathbf{8 . 6 1}$ & $\mathbf{5 . 8 2}$ & $\mathbf{1 1 . 0 9}$ & $\mathbf{5 . 5 3}$ \\
\hline
\end{tabular}

Figures having the same letter(s) in a column do not differ significantly by DMRT.

Level of significance $* *$ means significant at $1 \%$ level. 


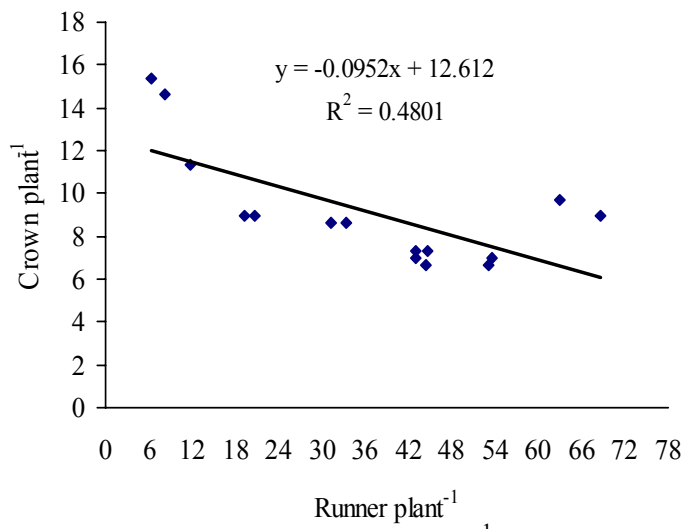

Figure 1: Relationship between number of runner plant ${ }^{-1}$ and number of crowns plant ${ }^{-1}$

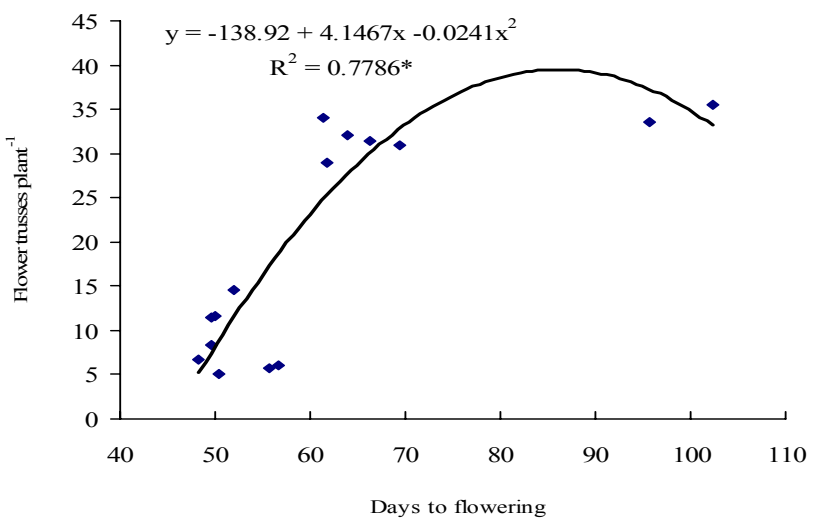

Figure 2: Relationship between days to flowering and number of flower trusses plant ${ }^{-1}$.

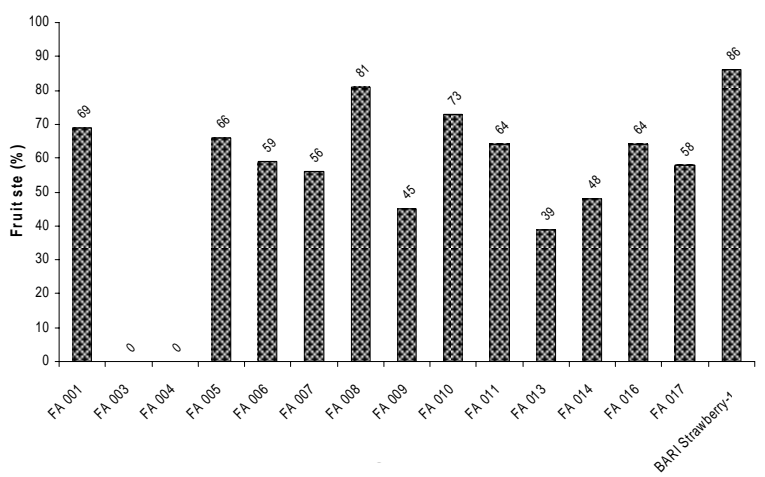

Germplasm

Figure 3: Fruit set (\%) in different strawberry germplasm.

Note. Plant of FA 003 and FA 004 failed to produce any fruits. 


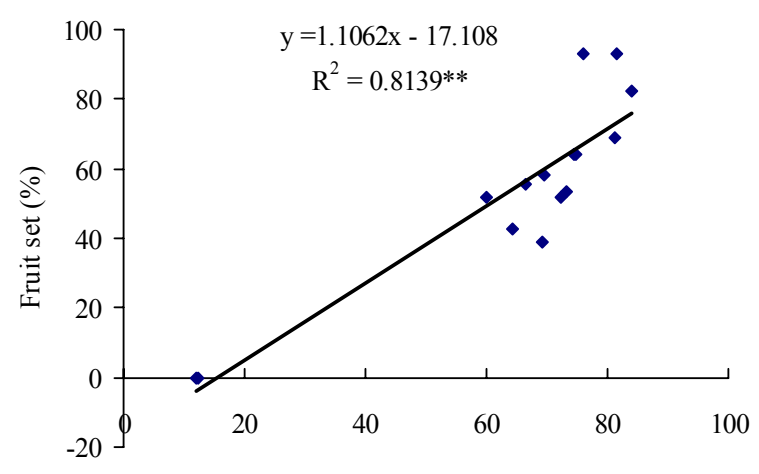

Pollen viability (\%)

Figure 4. Relationship between pollen viability and percent fruit set in straw berry

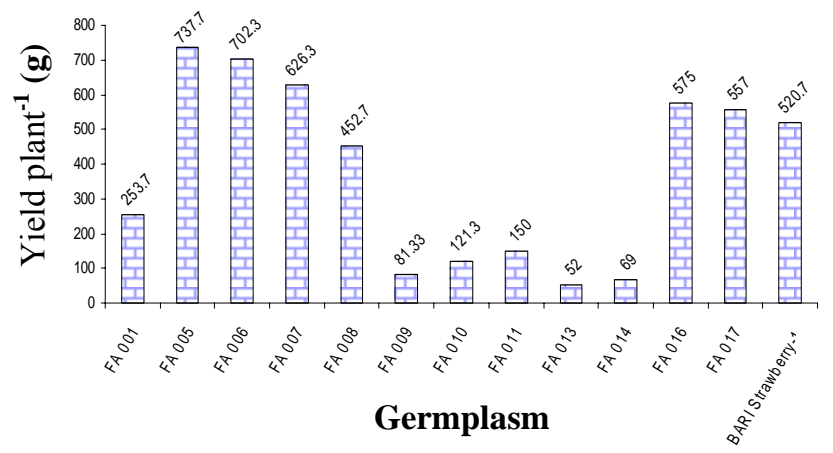

Figure 5: Yield plant ${ }^{-1}(\mathrm{~g})$ in different strawberry germplasm.

Appendix 1: Accession number, source of collection and country of origin of collected strawberry germplasm/varieties

\begin{tabular}{lll}
\hline \multicolumn{1}{c}{ Accession No. } & \multicolumn{1}{c}{ Source of collection } & \multicolumn{1}{c}{ Country of origin } \\
\hline FA 001 & BARI & Japan \\
FA 003 & Parvin Nursery & Unknown \\
FA 004 & Parvin Nursery & Unknown \\
FA 005 & Personal contact & Florida, USA \\
FA 006 & Personal contact & Florida, USA \\
FA 007 & Personal contact & Florida, USA \\
FA 008 & Rajshahi University & Japan \\
FA 009 & Rajshahi University & Japan \\
FA 010 & Rajshahi University & Japan \\
FA 011 & Kashban Nursery & India \\
FA 013 & Kashban Nursery & India \\
FA 014 & Parvin Nursery & India \\
FA 016 & Krishibid Nursery & Unknown \\
FA 017 & Krishibid Nursery & Unknown \\
BARI Strawberry-1 & BARI & Japan \\
\hline
\end{tabular}

